\begin{abstract}
Iranica
Abstracta Iranica Revue bibliographique pour le domaine irano-aryen

Volume 37-38-39 | 2018

Comptes rendus des publications de 2014-2016
\end{abstract}

\title{
Josette Elayi, Alain G. Elayi. « Arwad, cité phénicienne du nord»
}

\section{Astrid Nunn}

\section{(2) OpenEdition}

1 Journals

\section{Édition électronique}

URL : http://journals.openedition.org/abstractairanica/44226

DOI : 10.4000/abstractairanica.44226

ISBN : 1961-960X

ISSN : 1961-960X

Éditeur :

CNRS (UMR 7528 Mondes iraniens et indiens), Éditions de l'IFRI

Référence électronique

Astrid Nunn, « Josette Elayi, Alain G. Elayi. « Arwad, cité phénicienne du nord » », Abstracta Iranica [En ligne], Volume 37-38-39 | 2018, document 33, mis en ligne le 30 décembre 2018, consulté le 28 septembre 2020. URL : http://journals.openedition.org/abstractairanica/44226 ; DOI : https://doi.org/ 10.4000/abstractairanica.44226

Ce document a été généré automatiquement le 28 septembre 2020

Tous droits réservés 


\title{
Josette Elayi, Alain G. Elayi. « Arwad, cité phénicienne du nord»
}

\author{
Astrid Nunn
}

\section{RÉFÉRENCE}

Josette Elayi, Alain G. Elayi. «Arwad, cité phénicienne du nord », Transeuphratène (Supplément $\mathrm{n}^{\circ}$ 19), 2015, 254 p., 13 fig. et $15 \mathrm{pl}$.

1 Arwad est une île située à $2,5 \mathrm{~km}$ de la côte syrienne en face de Tartous. Jusqu'à la guerre actuelle, elle était une attraction touristique qui frappait e.a. par les énormes blocs de pierre appareillés. Ceux-ci sont difficilement datables mais pourraient remonter à l'époque perse. Arwad, par exemple déjà mentionnée dans les textes d'Ebla vers 2500 av. J.-C., est certainement habitée depuis une haute antiquité. On n'en connait toutefois presque rien, l'habitation et la reconstruction permanentes en ayant détruit les traces. Elles restent les sources lacunaires et très hétérogènes essentiellement couvertes par les monnaies et les textes accadiens (URU/KUR a-ru-a-da/a-ru-ad-da), phéniciens ( ${ }^{\mathrm{RWD}}$ ) et grecs (Arados), sur lesquelles cette monographie repose. L'île devra faire face à la domination assyrienne et babylonienne et deviendra à l'époque achéménide une cité phénicienne importante avec sa propre dynastie et son propre monnayage. Située au nord des autres grandes cités phéniciennes Byblos, Tyr et Sidon, Arwad entretenait des relations étroites avec Chypre et l'Anatolie. 


\section{AUTEURS}

\section{ASTRID NUNN}

Université de Munich 